\title{
A descriptive hospital based study of rotavirus diarrhoea in children aged 6 months to 3 years
}

\author{
Gursharan Singh $^{1}$, Gagan Deep Singh ${ }^{2}$, Sunita Arora ${ }^{1}$, Gurmeet Singh $^{3}$, Aruna Aggarwal $^{4}$
}

Sri Lanka Journal of Child Health, 2014; 43(4): 219-223

\begin{abstract}
Objective: To study the prevalence, demographic characteristics, clinical characteristics, laboratory parameters and therapy of rotavirus diarrhoea in children aged 6 months to 3 years in a hospital setting
\end{abstract}

Method: A prospective hospital based crosssectional study was carried out in Sri Guru Ramdas Institute of Medical Sciences and Research on 50 consecutive children aged 6 month to 3 years with diarrhoea from December 2011 to June 2013. Stool samples were collected and rotavirus antigen detection was done by the Enzyme Immunoassay method. Stool microscopy and culture were done to find out bacterial and other causes for diarrhoea. Data so obtained was statistically analysed.

Results: Out of 50 patients 22 tested positive for rotavirus by FAR diagnostic rotavirus card ELISA test. Prevalence of rotavirus diarrhoea in our study was $44 \%$. Rotavirus diarrhoea was found most commonly in 6-12 months age group and in the months of October to December. Most of the patients presented with some dehydration.

Conclusions: Prevalence of rotavirus diarrhoea in our hospital based study was $44 \%$. The consistency of stools was watery in a significant number of rotavirus diarrhoea patients compared to nonrotavirus patients $(\mathrm{p}<0.05)$. A significant number of cases with rotavirus diarrhoea had some dehydration compared to non-rotavirus patients $(\mathrm{p}<0.05)$.

(Key words: Rotavirus; prevalence; dehydration)

\section{Introduction}

There is a lack of nationally representative data on the incidence of severe rotavirus disease in India ${ }^{1}$. Previous studies in the Indian Rotavirus Strain Surveillance Network have confirmed that

${ }^{1}$ Professor, ${ }^{2}$ Junior Resident, ${ }^{3}$ Associate Professor Department of Paediatrics, ${ }^{4}$ Professor, Department of Microbiology, Sri Guru Ramdas Institute of Medical Sciences and Research, Sri Amritsar, India

(Received on 28 February 2014: Accepted after revision on 25 April 2014) rotavirus accounts for $39 \%$ of acute diarrhoeal hospitalizations $^{2}$. We aimed to study the prevalence, demographic characteristics, clinical characteristics, laboratory parameters and therapy of rotavirus diarrhoea in children between 6 months to 3 years.

\section{Method}

This is a hospital based prospective, cross sectional descriptive study done in Sri Guru Ramdas Institute of Medical Sciences and Research from December 2011 to June 2013. All children aged 6 months to 3 years with chief complaints of loose stools and/or vomiting, after receiving informed consent from parent/guardian, were included in the study. Children over 3 years of age were excluded from the study.

A case of diarrhoea was defined as increased stool frequency compared with the usual pattern for which parents sought care for treatment of diarrhoea. The indications for hospitalization were (i) severe dehydration requiring intravenous hydration (ii) malnourished children with dehydration (iii) toxic appearance, changing mental status (iv) high output diarrhoea ( $>10$ large volume stool/day) (vi) persistent vomiting or diminished or no oral intake (vii) suboptimal or no response to oral rehydration therapy (ORT) or further deterioration (viii) inability of the caregiver to administer oral rehydration salts (ORS) ${ }^{3}$.

History of fever, loose stools, vomiting and the duration of presenting complaints was obtained from the parent/guardian according to proforma. Data about exclusive breast feeding and about current feeding pattern was also assessed. Anthropometry was done to find out grade of malnutrition. Temperature, pulse and blood pressure was checked. Children were assessed for signs of dehydration and classified as per WHO Integrated Management of Childhood Illness Model Handbook guidelines and was categorized into severe, some or no dehydration ${ }^{3}$.

Stool samples of all the children presenting with diarrhoea were collected in sterile containers and tested in side laboratory in ward for presence or absence of rotavirus antigen. Other stool samples were sent to microbiology department of SGRDIMSR hospital for routine examination and 
stool culture and sensitivity. ELISA testing (Rotavirus card, FAR diagnostics) was used to test for Rotaviral antigens in stool. The enzyme-linked immune-sorbent assay is highly sensitive (100\%) and specific (97\%) for rotavirus antigen ${ }^{4}$.

Venous blood samples, collected under aseptic precautions, were sent for haemoglobin estimation, total and differential blood counts and serum electrolytes. A clean catch midstream urine sample was collected and subjected to routine examination and culture sensitivity.

Data was collected and entered in Microsoft Excel 2010. For inferential analysis, Chi-square and independent t-test were calculated at the level of significance $\mathrm{p}=0.05$ (Confidence interval $=95 \%$ ). Analysis was done using SPSS software, Version 11.5 .

\section{Results}

Stools samples of 50 patients presenting with acute diarrhoea were subjected to rotavirus card test and prevalence of rotavirus diarrhoea was found to be $44 \%(n=22)$ (Figure 1).

\section{ROTAVIRUS CARD TEST}

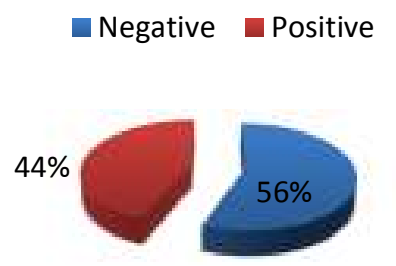

Figure 1: Prevalence of rotavirus diarrhoea in study group

The demographic characteristics and feeding pattern of the 50 patients are shown in Table 1.

Table 1: Demographic characteristics and feeding pattern

\begin{tabular}{|c|c|c|c|c|}
\hline & & $\begin{array}{c}\text { Rotavirus present } \\
(\mathrm{n}=22)\end{array}$ & $\begin{array}{c}\text { Rotavirus absent } \\
(n=28)\end{array}$ & P value \\
\hline \multirow[t]{5}{*}{ Age group (Months) } & $6-12$ & $08(36 \%)$ & $09(32 \%)$ & \multirow{5}{*}{0.828} \\
\hline & $13-18$ & $05(22 \%)$ & $07(25 \%)$ & \\
\hline & $19-24$ & $06(27 \%)$ & $09(32 \%)$ & \\
\hline & $25-30$ & $02(09 \%)$ & $03(11 \%)$ & \\
\hline & $31-36$ & $01(04 \%)$ & - & \\
\hline \multirow[t]{2}{*}{ Gender } & Male & $09(40 \%)$ & $17(60 \%)$ & \multirow[t]{2}{*}{0.626} \\
\hline & Female & $13(60 \%)$ & $11(40 \%)$ & \\
\hline \multirow[t]{4}{*}{ Seasonality } & January-March & $05(22 \%)$ & $05(17 \%)$ & \\
\hline & April-June & $01(07 \%)$ & $04(14 \%)$ & \\
\hline & July-September & $07(31 \%)$ & $15(53 \%)$ & \\
\hline & October-December & $09(40 \%)$ & $04(14 \%)$ & \\
\hline \multicolumn{2}{|c|}{ Exclusive breast feeding for 6 months } & $15(68 \%)$ & $20(71 \%)$ & 0.630 \\
\hline \multirow[t]{3}{*}{ Current feeding pattern } & Only breast feed & $02(09 \%)$ & $05(17 \%)$ & \multirow{3}{*}{0.634} \\
\hline & Breast + bottle feed & $15(68 \%)$ & $17(66 \%)$ & \\
\hline & Bottle feed & $05(22 \%)$ & $05(17 \%)$ & \\
\hline \multirow[t]{4}{*}{ Nutritional status } & No malnutrition & $11(50 \%)$ & $12(42 \%)$ & \multirow{4}{*}{0.55} \\
\hline & Grade 1 & $08(36 \%)$ & $07(25 \%)$ & \\
\hline & Grade 2 & $02(09 \%)$ & $06(21 \%)$ & \\
\hline & Grade 3 & $01(05 \%)$ & $03(12 \%)$ & \\
\hline
\end{tabular}

The clinical characteristics of the 50 patients are shown in Table 2. 
Table 2: Clinical characteristics

\begin{tabular}{|c|c|c|c|c|c|}
\hline \multicolumn{3}{|c|}{ Characteristic } & Rotavirus positive $(n=22)$ & Rotavirus negative $(n=28)$ & P value \\
\hline \multicolumn{3}{|c|}{ Fever } & $13(59 \%)$ & $15(53 \%)$ & 0.696 \\
\hline \multirow{2}{*}{$\begin{array}{l}\text { Stool } \\
\text { consistency }\end{array}$} & \multicolumn{2}{|c|}{ Semi-formed } & $03(14 \%)$ & $10(36 \%)$ & \multirow[t]{2}{*}{0.047} \\
\hline & \multicolumn{2}{|l|}{ Watery } & $19(86 \%)$ & $18(64 \%)$ & \\
\hline \multirow{4}{*}{$\begin{array}{l}\text { Stool } \\
\text { frequency }\end{array}$} & \multicolumn{2}{|l|}{ 6-10 Times } & $02(09 \%)$ & $08(28 \%)$ & \multirow{4}{*}{0.33} \\
\hline & \multicolumn{2}{|l|}{ 11-15 Times } & $10(45 \%)$ & $08(28 \%)$ & \\
\hline & \multicolumn{2}{|c|}{ 16-20 Times } & $08(36 \%)$ & $09(32 \%)$ & \\
\hline & \multicolumn{2}{|l|}{$>20$ Times } & $02(09 \%)$ & $03(12 \%)$ & \\
\hline Mucus & \multicolumn{2}{|l|}{ Present } & $10(45 \%)$ & $14(50 \%)$ & 0.749 \\
\hline \multirow[t]{3}{*}{ Stool colour } & \multicolumn{2}{|l|}{ Watery } & $14(63 \%)$ & $15(53 \%)$ & \multirow{3}{*}{0.745} \\
\hline & \multicolumn{2}{|l|}{ Green } & $02(09 \%)$ & $04(15 \%)$ & \\
\hline & \multicolumn{2}{|l|}{ Yellow } & $06(27 \%)$ & $09(32 \%)$ & \\
\hline \multirow{4}{*}{$\begin{array}{l}\text { Duration of } \\
\text { diarrhoea }\end{array}$} & \multicolumn{2}{|c|}{ 1-2 days } & $05(22 \%)$ & $05(19 \%)$ & \multirow{4}{*}{0.581} \\
\hline & \multicolumn{2}{|c|}{ 3-4 days } & $10(45 \%)$ & $12(42 \%)$ & \\
\hline & \multicolumn{2}{|c|}{ 5-6 days } & $06(27 \%)$ & $11(39 \%)$ & \\
\hline & \multicolumn{2}{|c|}{$>6$ days } & $01(04 \%)$ & - & \\
\hline \multirow{3}{*}{$\begin{array}{l}\text { Degree of } \\
\text { dehydration }\end{array}$} & \multicolumn{2}{|l|}{ No } & $04(18 \%)$ & $12(42 \%)$ & \multirow[t]{3}{*}{0.039} \\
\hline & \multicolumn{2}{|l|}{ Some } & $15(68 \%)$ & $09(32 \%)$ & \\
\hline & \multicolumn{2}{|l|}{ Severe } & $03(13 \%)$ & $07(25 \%)$ & \\
\hline \multirow[t]{8}{*}{$\begin{array}{l}\text { Signs of } \\
\text { dehydration }\end{array}$} & $\begin{array}{l}\text { Anterior } \\
\text { fontanelle }\end{array}$ & Depressed & $15(68 \%)$ & $13(46 \%)$ & 0.048 \\
\hline & \multirow[t]{3}{*}{ Thirst } & Present & $03(13 \%)$ & $12(42 \%)$ & \multirow{3}{*}{0.011} \\
\hline & & Increased & $16(74 \%)$ & $15(53 \%)$ & \\
\hline & & Absent & $03(13 \%)$ & $01(03 \%)$ & \\
\hline & Eyes & Sunken & $18(81 \%)$ & $15(53 \%)$ & 0.012 \\
\hline & Mucosa & Dry & $18(81 \%)$ & $15(53 \%)$ & 0.014 \\
\hline & \multirow[t]{2}{*}{ Skin turgor } & Slow & $15(68 \%)$ & $09(32 \%)$ & 0.039 \\
\hline & & Slow $>2 s$ & $03(13 \%)$ & $07(25 \%)$ & \\
\hline
\end{tabular}

The consistency of stools was watery in a significant number of rotavirus diarrhoea patients $\left(\mathrm{X}^{2}=3.121, \mathrm{p}\right.$ value $\left.=0.047, \mathrm{df}=1\right)$ compared to nonrotavirus patients. A significant number of cases with rotavirus diarrhoea had some dehydration. $\left(\mathrm{X}^{2}\right.$ $=6473, \mathrm{p}=0.039, \mathrm{df}=2$ ) compared to non-rotavirus patients. Signs of dehydration significantly associated with rotaviral diarrhoea were depressed anterior fontanelle $\left(\mathrm{X}^{2}=4.026, \mathrm{p}=0.048, \mathrm{df}=2\right)$, increased thirst $\left(\mathrm{X}^{2}=8.981, \mathrm{p}=0.011, \mathrm{df}=2\right)$, dry mucosa $\left(\mathrm{X}^{2}=6.088, \mathrm{p}=0.014, \mathrm{df}=1\right)$ and diminished skin turgor $\left(\mathrm{X}^{2}=6.473, \mathrm{p}=0.039, \mathrm{df}=2\right)($ Table 2).

The laboratory parameters of the 50 patients are shown in Table 3. Treatment of the patients in study group was done as per WHO guidelines according to degree of dehydration (Table 4).

Table 3: Laboratory parameters

\begin{tabular}{|c|c|c|c|c|}
\hline & & $\begin{array}{c}\text { Rotavirus } \\
\text { positive }(n=22)\end{array}$ & $\begin{array}{c}\text { Rotavirus } \\
\text { negative }(n=28)\end{array}$ & P value \\
\hline Anaemia & $\begin{array}{l}\text { Moderate - Severe } \\
(5-8 \mathrm{~g} / \mathrm{dl})\end{array}$ & $03(13 \%)$ & $05(17 \%)$ & 0.194 \\
\hline \multirow[t]{3}{*}{ Total leukocyte count } & $3000-6000 / \mathrm{cu} \mathrm{mm}$ & $07(31 \%)$ & $08(28 \%)$ & \multirow[t]{3}{*}{0.240} \\
\hline & $6100-9000 / \mathrm{cu} \mathrm{mm}$ & $11(50 \%)$ & $09(32 \%)$ & \\
\hline & $>9000 / \mathrm{cu} \mathrm{mm}$ & $04(19 \%)$ & $11(39 \%)$ & \\
\hline Urine $\mathrm{R} / \mathrm{E}$ & $>5$ leucocytes/hpf & $10(45 \%)$ & $08(28 \%)$ & 0.120 \\
\hline \multirow[t]{4}{*}{ Stool R/E } & Many pus cells & $02(09 \%)$ & $10(35 \%)$ & \multirow[t]{4}{*}{0.110} \\
\hline & Reducing substance & $01(4.5 \%)$ & $01(3.5 \%)$ & \\
\hline & Cyst/Trophozoite (Giardia) & $01(4.5 \%)$ & $01(3.5 \%)$ & \\
\hline & Vibrio Cholerae & - & $01(3.5 \%)$ & \\
\hline \multirow{4}{*}{$\begin{array}{l}\text { Electrolyte } \\
\text { abnormalities }\end{array}$} & Hyponatraemia & $03(13 \%)$ & $06(21 \%)$ & \multirow[t]{4}{*}{0.687} \\
\hline & Hypernatraemia & $04(18 \%)$ & $05(17 \%)$ & \\
\hline & Hypokalaemia & $01(4.5 \%)$ & $02(07 \%)$ & \\
\hline & Hyperkalaemia & - & - & \\
\hline
\end{tabular}


Table 4: Treatment plan and duration of hospital stay

\begin{tabular}{|c|c|c|c|c|}
\hline & & $\begin{array}{c}\text { Rotavirus } \\
\text { positive }(n=22)\end{array}$ & $\begin{array}{c}\text { Rotavirus } \\
\text { negative }(n=28)\end{array}$ & P value \\
\hline \multicolumn{2}{|l|}{ Intravenous fluid requirement } & $18(81 \%)$ & $18(64 \%)$ & 0.171 \\
\hline \multirow[t]{3}{*}{ Duration of Oral rehydration therapy } & $0-2$ days & $06(27 \%)$ & $08(28 \%)$ & \multirow{3}{*}{0.357} \\
\hline & 3-4 days & $10(46 \%)$ & $13(46 \%)$ & \\
\hline & 5-6 days & $06(27 \%)$ & $07(25 \%)$ & \\
\hline \multicolumn{2}{|l|}{ Use of antibiotics } & $03(13 \%)$ & $08(28 \%)$ & 0.261 \\
\hline \multirow[t]{4}{*}{ Duration of hospital stay } & No & $04(18 \%)$ & $13(46 \%)$ & \multirow{4}{*}{0.153} \\
\hline & 1-3 days & $14(63 \%)$ & $09(32 \%)$ & \\
\hline & 4-6 days & $04(18 \%)$ & $02(07 \%)$ & \\
\hline & $>7$ days & - & $04(14 \%)$ & \\
\hline
\end{tabular}

Oral rehydration solution (ORS) was given to all 50 patients. Oral zinc was given for 14 days in all patients.

\section{Discussion}

In our hospital-based study we found a prevalence of rotavirus diarrhoea of $44 \%$. Mathew et al in Ernakulam district, Kerala also detected rotavirus in $36 \%$ of diarrhoea-related hospital admissions among children less than 5 years of age ${ }^{5}$. In our study $36 \%$ of rotavirus positive cases were in the 6 12 month age group and $27 \%$ cases in the $19-24$ month age group. Similar results were reported in a study by Mathew et al who reported high prevalence in children aged $6-11$ months and 1223 months $\left(32 \%\right.$ and $42 \%$, respectively) ${ }^{5}$. A study by Grimwood et al in New Zealand also showed rotavirus detection rate to be $27 \%$ in infants aged $0-5$ months, $43 \%$ in infants aged $6-11$ months, and $52 \%$ in the $12-35$ month age group $(\mathrm{p}<0.001)^{6}$.

Of the 22 patients with rotavirus diarrhoea in our study $40 \%$ were male. Proportion of male and female patients were $53 \%$ and $47 \%$ respectively in a study done by Azemi $\mathrm{M}$ et al in Kosovo ${ }^{7}$. In our study we found that $40 \%$ of cases with rotavirus diarrhoea were seen from October-December and $31 \%$ from July-September. Most studies have observed an increase in rotavirus-associated diarrhoea during the winter months, October to February, throughout the country ranging from $59 \%$ to $72 \%$, with a median of $64 \%$. The northern, more temperate regions may exhibit stronger seasonality ${ }^{8}$. However Dey SK, Hayakawa Y. et al observed that $50 \%$ children from Bangladesh were afflicted by rotavirus during the summer?

In our study, exclusive breast feeding for 6 months did not have any impact on distribution of rotavirus diarrhoea. Similar results were observed by Wobudeya $\mathrm{E}$ et al in a case controlled study in Uganda $^{10}$ and by Golding $\mathrm{J}$ et al in infants aged 4 6 months ${ }^{11}$. In our study the nutritional status was not significantly associated with rotavirus diarrhoea. Bern $\mathrm{C}$ et al observed no significant difference in prevalence of rotavirus diarrhoea and severity of dehydration in children with or without malnutrition in Bangladesh ${ }^{12}$.

We found that fever was present in 59\% patients, vomiting in $50 \%$ patients and diarrhoea in $100 \%$ patients with rotavirus gastroenteritis. Duration of diarrhoea was 3-6 days in $45 \%$ cases. Similar results were seen in a study conducted by Azemi $\mathrm{M}$, et al where the most dominant symptom was diarrhoea $(98.6 \%)$ followed by vomiting $(88 \%)$. The average duration of diarrhoea was 5 days $^{7}$. In our study the consistency of stools was watery in $86 \%$ cases. Azemi M, et al observed that the stools were watery in the majority of cases ${ }^{7}$.

In our study $68 \%$ of rotavirus cases had moderate dehydration and 13\% severe dehydration. Mathew et al found moderate dehydration in $49 \%$ of cases and severe dehydration in $14 \%$ of cases ${ }^{5}$. Sherchand JB et al. in Nepal in 2010 observed that the degree of dehydration among rotavirus cases was more likely to be moderate to severe rather than mild ${ }^{13}$. In our study, increased thirst, depressed anterior fontanelle and dry mucosa were significantly associated with rotavirus diarrhoea as compared to non-rotavirus diarrhoea. In our study no electrolyte abnormalities were present in $64.5 \%$ of cases with rotavirus diarrhoea and hypernatraemia was present in $18 \%$ cases. Azemi $\mathrm{M}$ et al in 2012 also observed no electrolyte abnormality in $64.1 \%$ patients. Only $9.85 \%$ of patients suffered hypernatremia ${ }^{7}$.

In our study ORS and oral zinc were given to all 50 patients. Intravenous fluids were needed in $81 \%$ patients with rotavirus diarrhoea and $64 \%$ patients with non-rotaviral diarrhoea. Nalin DR et al observed that oral therapy is safe and effective for rehydration in most infants with $5-10 \%$ dehydration due to viral or bacterial diarrhoea ${ }^{14}$. In our study we found that the mean hospital stay in rotavirus diarrhoea was $3 \pm 2$ days as compared to $4 \pm 1$ days in non rotaviral group. Kurugol $\mathrm{Z}$ et al on the other hand observed that the mean hospital stay for rotavirus gastroenteritis was significantly longer $5.5 \pm 5.1$ days compared to $3 \pm 3.1$ days for nonrotavirus gastroenteritis ${ }^{15}$. 


\section{Conclusions}

- In the 6 month-3 year age group the prevalence of rotavirus diarrhoea was $44 \%$ in our hospitalbased study.

- The consistency of stools was watery in a significant number of rotavirus diarrhoea patients compared to non-rotavirus patients $(\mathrm{p}<0.05)$.

- A significant number of cases with rotavirus diarrhoea had some dehydration compared to non-rotavirus patients $(\mathrm{p}<0.05)$.

\section{References}

1. Khan G, Fitzwater S, Tate JE, Kang G, Ganguly N, Nair G, et al. Epidemiology and prospects for prevention of rotavirus disease in India. Indian Pediatrics 2012; 49:467-74. http://dx.doi.org/10.1007/s13312-012-0076-7

2. Kang G, Arora R, Chitambar SD, Deshpande J, Gupte MD, Kulkarni M, et al. Multicenter, hospital-based surveillance of rotavirus disease and strains among Indian children aged $<5$ years. Journal of Infectious Disease 2009; 200:S147-53.

http://dx.doi.org/10.1086/605031

3. World Health Organization. The treatment of diarrhoea: a manual for physicians and other senior health workers, $4^{\text {th }}$ ed. Geneva: World Health Organization. 2005.

4. Beards GM, Campbell AD, Cottrell NR, Peiris JS, Rees N, Sanders RC, et al. Enzyme-linked immunosorbent assays based on polyclonal and monoclonal antibodies for rotavirus detection. Journal of Clinical Microbiology 1984; 19 (2): 248-54.

5. Mathew MA, Paulose A, Chitralekha S, Nair MK, Kang G, Kilgore P. Prevalence of rotavirus diarrhoea among hospitalized children less than 5 Years in Kerala, South India: Indian Pediatrics 2014; 51(1): 27-31. http://dx.doi.org/10.1007/s13312-014-0329-8

6. Grimwood K, Huang QS, Cohet C, Gosling IA, Hook SM, Teele DW, et al. Rotavirus hospitalisation in New Zealand children under 3 years of age. Journal of Paediatrics \& Child Health 2006; 42(4): 196-203.

http://dx.doi.org/10.1111/j.14401754.2006.008 29.x

7. Azemi M, Berisha M, Ismaili-Jaha V, Kolgeci S, Avdiu M, Jakupi X, et al :Socio- demographic, clinical and laboratory features of rotavirus gastroenteritis in children treated in paediatric clinic. Mater Sociomed. 2013; 25(1):9-13. http://dx.doi.org/10.5455/msm.2013.25.9-13

8. Parashar UD, Gibson CJ, Bresse JS, Glass RI. Rotavirus and severe childhood diarrhoea. Emerg Infect Dis 2006; 12:304-6. http://dx.doi.org/10.3201/eid1202.050006

9. Dey SK, Hayakawa Y, Rahman M, Islam R, Mizuguchi M, Okitsu S, et al. G2 strain of rotavirus among infants and children, Bangladesh. Emerg Infect Dis. 2009; 15(1):914. $\underline{\text { http://dx.doi.org/10.3201/eid1501.080883 }}$

10. Wobudeya E, Bachou H, Karamagi CK, Kalyango JN, Mutebi E, Wamani $\mathrm{H}$ et al: Breastfeeding and the risk of rotavirus diarrhoea in hospitalized infants in Uganda: a matched case control study; BMC Pediatrics 2011; 11:17 http://dx.doi.org/10.1186/1471-2431-11-17

11. Golding J, Emmett PM, Rogers IS: Gastroenteritis, diarrhoea and breast feeding. Early Hum Dev 1997; 49 Suppl: S83-103. http://dx.doi.org/10.1016/S03783782(97)0005 $\underline{5-8}$

12. Bern C, Unicomb L, Gentsch JR, Banul N, Yunus M, Sack RB et al: Rotavirus Diarrhoea in Bangladeshi Children: Correlation of Disease Severity with Serotypes; J Clin Microbiol. 1992; 30(12):3234-8

13. Sherchand JB ,Schlute WW, Sherchan JB, Tandukar S, Dhakwa JR, Choudhary G R et al :Prevalence of group A genotype human rotavirus among children with diarrhoea in Nepal, 2009-2011;WHO South-East Asia Journal of Public Health 2012;1(4):432-40.

14. Nalin DR, Levine MM, Mata L, de Céspedes C, Vargas W, Lizano $\mathrm{C}$ et al: Oral rehydration and maintenance in children with rotavirus and bacterial diarrhoea; Bull World Health Organisation 1979; 57(3):453-9.

15. Kurugöl Z, Geylani S, Karaca Y, Umay F, Erensoy S, Vardar $F$ et al. Rotavirus gastroenteritis among children under five years of age in Ýzmir, Turkey. Turkish Journal of Pediatrics 2003; 45(4):290-4. 